\title{
A REPRESENTATIVIDADE DO SALTO ALTO
}

\author{
LA REPRESENTATIVIDAD DEL TACÓN ALTO
}

THE REPRESENTATIVITY OF THE HIGH HEEL

\author{
Renan Martins da Conceição ATTAB ${ }^{1}$ \\ Priscila da Silva FERNANDES ${ }^{2}$
}

RESUMO: Esse trabalho tem por objetivo compreender como o salto alto esteve presente por tanto tempo no processo evolutivo sociocultural, abordando as consequências que esse tipo de calçado produzia, principalmente no ambiente de trabalho, desmitificando o poder de fascinação que ele provoca nas mulheres e compreender a questão do fetiche masculino com relação a esse objeto. Como metodologia, foi realizada uma pesquisa na qual se analisou fatos históricos, blogs e artigos científicos para o desenvolvimento teórico. Como resultado, obtevese que o uso do salto alto no cotidiano pode ser muito prejudicial à coluna e às pernas da mulher e que o uso desse calçado é fruto de uma cultura machista, fundamentada no fetichismo do imaginário masculino.

PALAVRAS-CHAVE: Salto alto. Fetiche. Poder.

RESUMEN: Este trabajo tiene como objetivo comprender cómo los tacones altos han estado presentes durante tanto tiempo en el proceso evolutivo sociocultural, abordando las consecuencias que produjo este tipo de calzado, especialmente en el ámbito laboral, desmitificando el poder de fascinación que provoca en las mujeres y entendiendo el tema del fetiche masculino con respecto a ese objeto. Como metodología se realizó una investigación en la que se analizaron hechos históricos, blogs y artículos cientificos para su desarrollo teórico. Como resultado, se encontró que el uso de tacones altos en la vida diaria puede ser muy dañino para la columna y las piernas de las mujeres y que el uso de estos zapatos es el resultado de una cultura machista, basada en el fetichismo de la imaginación masculina.

PALABRAS CLAVE: Tacones altos. Fetiche. Poder.

ABSTRACT: This work aims to understand how high heels have been present for so long in the socio-cultural evolutionary process, addressing the consequences that this type of footwear produced, especially in the work environment, demystifying the power of fascination it causes in women and understanding the issue of the male fetish with respect to that object. As a methodology, a research was carried out in which historical facts, blogs and scientific articles were analyzed for theoretical development. As a result, it was found that the use of high heels

${ }^{1}$ Universidade Estadual Paulista (UNESP), Araraquara - SP - Brasil. Mestrando no Programa de Pós-graduação em Educação Sexual. ORCID: https://orcid.org/0000-0001-9059-1331. E-mail: renanattab@unesp.br

${ }^{2}$ Universidade Estadual Paulista (UNESP), Araraquara - SP - Brasil. Mestranda no Programa de Pós-graduação em Educação Sexual. ORCID: https://orcid.org/0000-0002-0717-7816. E-mail: priscila-silva.fernandes@unesp.br

RPGE- Revista on line de Política e Gestão Educacional, Araraquara, v. 24, n. esp. 3, p. 1793-1808, dez. 2020. e-ISSN:1519-9029 
in daily life can be very harmful to the spine and legs of women and that the use of these shoes is the result of a machoistic culture, based on the fetishism of the male imagination.

KEYWORDS: High heels. Fetish. Power.

\section{Introdução}

O salto alto está presente na história da humanidade desde a Antiguidade, começando pelo Antigo Egito, onde o uso de calçados semelhantes à plataforma era somente utilizado por aqueles que possuíam um status social superior, ou seja, a nobreza. Na Grécia e Roma antigas, o uso desse objeto era muito presente entre artistas que compunham as peças teatrais. Nessa época, o salto era produzido a partir de uma madeira ou cortiça, cujo artista que tinha o maior destaque utilizava o maior salto alto (ESTEVÃO, 2018). Na idade Média, segundo Estevão, (2018), esse calçado era utilizado tanto por homens quanto por mulheres, pois o objetivo desse objeto era evitar que os pés se sujassem na lama e nos excrementos devido à falta de saneamento básico; contudo os açougueiros também utilizavam para não terem contato com o sangue dos animais mortos, conforme cita Estevão (2018). Já as prostitutas utilizavam com a intenção de seduzir os homens e, consequentemente, esse ato aproximava o salto alto do universo feminino.

No Renascimento, o salto alto foi utilizado pela cavalaria da Pérsia dando equilíbrio para os arqueiros. As pessoas da realeza como Catherine de Médici e o rei Luís XIV também optaram pelo uso do salto alto devido ao complexo que estes apresentavam em relação as suas estaturas. Isso fez com que a nobreza aderisse em massa a esse calçado que, segundo Marreto (2018) além de elevar a altura, mostrava segurança e equilíbrio. Com a Revolução Industrial e a luta de igualdade de classes o salto alto desapareceu por um tempo, retornando apenas nos anos de 1800, sendo difundido por toda América através de um modelo com um salto menor e que agilizava a locomoção. Já na China do século X, segundo Barreiros, (2019), havia uma tradição cultural e supersticiosa a realização de bons casamentos através de mulheres que possuíam o pé pequeno, no máximo $10 \mathrm{~cm}$; no entanto, para que isso ocorresse, as mulheres aprendiam, desde a infância, o costume de amarrar os pés para que estes não se desenvolvessem.

$\mathrm{Na}$ atualidade, existe a ilusão no imaginário das meninas e também o poder que o modelo patriarcal impregnou no ilusório feminino de que a mulher fica linda e poderosa com o salto alto, sendo essa ideia cultivada desde a sua primeira infância até sua vida adulta, fazendo com que a mulher frequente festas e o mundo do trabalho com esse objeto empoderador, mas ao mesmo tempo torturador. A simbologia desse objeto no mundo feminino é muito forte, principalmente na cabeça dos homens, causando, em muitos, o fetiche em seu mundo utópico, 
chegando até no mundo do trabalho, no qual muitas empresas obrigam suas funcionárias a utilizarem o salto alto, principalmente as que exercem algum cargo de poder ou liderança, pois atribuem a capacidade dessa mulher ao uso desse objeto. O contorno que esse sapato propicia ao corpo feminino coloca a mulher em uma posição no imaginário sexual masculino, muitas vezes considerado por eles como mero objeto de desejos sexuais.

Esse trabalho está baseado nos aspectos qualitativos que foram analisados em artigos científicos e blogs relacionados com a temática da pesquisa.

\section{História do salto alto}

A tecnologia do século XXI faz com que a indústria calçadista masculina e feminina apresente uma diversidade imensa de matérias-primas utilizadas na confecção e elaboração de calçados resultando em uma diversidade de formatos, cores e modelos, agradando a todos os tipos de público. No entanto, não importa se o modelo escolhido é uma sandália de design ousado, um salto alto cravejado em cristais que mais parece uma joia, uma palmilha que, de tão macia, parece uma espuma, ou um sapato social masculino com o formato interno tão macio quanto de um tênis, conforme apresenta o blog RBS (s/d). Estes são exemplos dos desafios que a indústria de calçados enfrenta para atender às preferências atuais, o número um do consumidor que é o conforto, sendo este um fator essencial que reformulará a elaboração e produção dos sapatos do futuro.

Quando o assunto é sapato feminino, principalmente sapatos com saltos, as opiniões das mulheres são bem diversificadas, pois há aquelas que preferem sapatos com salto baixo (com menos de $6 \mathrm{~cm}$ ) e há aquelas que preferem sapatos com salto médio (entre 6 e $8,5 \mathrm{~cm}$ ) e também há aquelas que preferem os sapatos com salto alto (com mais de 8,5 cm). Contudo, a grande maioria das mulheres tem ou já teve, em algum momento de sua vida, um sapato de salto alto como por exemplo os scarpins, que apresentam uma característica sexy, minimalista, transformando qualquer produção. Para o campo da moda contemporânea, o salto alto abstevese da simbologia do termo acessório que complementa todo um conjunto de vestimenta para se transformar em verdadeira joia, muitas vezes com valores substanciais e de cifras tão imponentes como as cifras de verdadeiros diamantes. Ainda nos dias de hoje, as mulheres utilizam o salto alto como forma de elevar a altura e de demonstração de requinte; contudo, existem fatos que evidenciam que o surgimento desse sapato estava atrelado a ideias bem diferenciadas das quais temos conhecimento, pois, na verdade, o salto alto inicialmente foi desenvolvido para pés masculinos; porém é uma incógnita quem inventou esses calçados. 
Também existe outro equívoco que, segundo Mylius (1998, apud BRITO, 2013) em seu artigo "Uma análise acerca da hegemonia dos sapatos de saltos altos ao longo da história", descreve que o tamanco não deve ser considerado um calçado de salto alto devido ao seu formato, tema que também se encontra segundo Brito (2013) no livro "Shoes”, escrito pela autora Linda O'Keeffe, que também fala das considerações erradas de tamancos cobertos por couro sendo considerados sapato de salto alto.

Dentro desse contexto histórico, o sapato de salto alto tem sua origem datada de 3500 a.C. no antigo Egito, relatado por Estevão (2018), no blog "Metrópoles", no qual existem imagens em murais mostrando o poder da nobreza que usava uma versão primitiva dessa plataforma, para assim ocasionar uma distinção entre as classes sociais, já que a plebe andava descalça. Segundo o mesmo autor, na Grécia e Roma antigas, o salto teve origem dentro do teatro, pois enquanto estavam no palco, os atores usavam plataformas com base de quatro polegadas em madeira ou cortiça. No entanto, como aponta Estevão (2018), a altura era proporcional ao status do personagem representado nos dramas e nas comédias. Esse mesmo autor relata que, por volta de 200 a.C., os romanos adotaram a ideia e chamaram os sapatos de kothorni.

Para Estevão (2018), o salto alto era mais que um símbolo de status. Na Idade Média (entre 1400 e 1600), houve o surgimento de uma espécie de calçado no qual o solado era de madeira empilhada ou de cortiça, tornando-se o precursor do salto alto e recebendo o nome de chopines. Estes sapatos de salto alto tinham como função, segundo Marreto (2018), manter os pés longe da lama e de outros detritos das ruas, pois, como não existia nessa época saneamento básico, havia nas ruas todas as formas de sujeira e excrementos. Estevão (2018), no blog "Metrópoles", descreve que, com uma anatomia excêntrica e um salto de $45 \mathrm{~cm}$, esse modelo virou moda, principalmente entre as prostitutas, pois atraía olhares do público masculino. Já Marreto (2018) nos descreve que os açougueiros usavam os calçados para não ficarem perto de todo aquele sangue no chão. Assim, para Estevão (2018), é a partir desse momento que o acessório se aproximou do universo feminino, e tanto homens quanto mulheres circulavam com as plataformas. No entanto, Estevão (2018) descreve que passaram a moldar e diferenciar os sapatos por gênero: as versões pontiagudas e finas eram pertencentes às damas e os modelos mais grossos eram utilizados pelos cavalheiros. Porém, como apresenta Marreto (2018), as mulheres precisavam de bengalas ou da ajuda dos servos para ficarem em pé. Segundo a mesma autora, em alguns países, as mulheres dos haréns eram obrigadas a usar sapatos de salto alto, já que estes dificultavam a fuga delas. Contudo, para Marreto (2018), em 1430, os chopines foram proibidos em Veneza, mas como nenhuma tendência de moda pode ser censurada, os 
venezianos se tornaram os responsáveis por transverter esses sapatos em peças extremamente luxuosas, as quais simbolizavam o status, a riqueza e a posição social das pessoas.

Em 1500, época do Renascimento, segundo Hancock (2018), o salto foi o grande aliado dos cavaleiros da Pérsia, já que a extremidade mais alta das botas auxiliavam os arqueiros a se manterem equilibrados durante o processo de atirar flechas. A novidade do salto somente se espalhou pela aristocracia ocidental no final do século XVI, época em que os persas buscaram o apoio na Europa contra o Império Otomano. Aos poucos, foram entrando em cena os saltos mais finos, considerados também mais elegantes. Na França, segundo Marreto (2018), em 1530, Catherine de Médici se casou, aos 14 anos, com o Duque de Orleans, futuro rei da França, no entanto, por ter uma estatura baixa e um corpo muito magro, essas características fizeram com que a duquesa se sentisse insegura ao lado do noivo, como solução de seus problemas, Catherine encomendou um par de sapatos que fizessem com que ela ficasse mais alta, ocasionando um verdadeiro sucesso perante a nobreza. Com isso, segundo Gonzaga (s/d), nobres aderiram em massa ao salto que, além de elevar a altura, mostrava segurança e equilíbrio.

Cerca de 200 anos depois, segundo Estevão (2018), a moda do salto alto foi lançada pelo rei Luís XIV, o qual possuía um complexo em relação a sua baixa estatura (que era de 1,60 m) tendo como única forma de se tornar mais alto, aumentar o salto dos seus sapatos, colocando, assim, a moda do salto alto como regra de vestuário, pois, além da utilidade estética, o salto servia para distinguir a nobreza da plebe, já que somente os membros que compunham a corte eram autorizados a usarem sapatos de salto como os dele. Porém, além da moda dos sapatos de salto, abusava do luxo das perucas. Devido à fixação por sapatos de salto, Luís XIV investiu em versões quadradas e ornamentadas por laços e fivelas, segundo Estevão (2018). Seus sapatos eram conhecidos por talon rouge, pois tinham como marca registrada o salto vermelho (detalhe: o restante do sapato poderia ser de outra cor, mas os saltos eram obrigatoriamente vermelhos, pois esta cor representava o poder e a nobreza). Nessa época, a França, mesmo ainda sendo dominada pela Espanha, tornou-se referência em moda na Europa e o Palácio de Versalhes era a verdadeira passarela de moda para desfiles de nobres glamourosos. Contudo, para Gonzaga (s/d), na Europa do século XVII, mesmo com a consolidação do salto alto através da nobreza, tanto homens como mulheres tinham de ser transportados em cadeirinhas carregadas por criados, pois não conseguiam caminhar no calçamento de pedras. Essa exaltação só foi finalizada com a Revolução Industrial, quando os hábitos de superioridade defendidos pela nobreza se tornaram inadequados dentro da sociedade devido ao movimento de igualdade de classes sociais, como resultado disso houve o sumiço dos sapatos de saltos, voltando à moda por volta de 1800, conquistando toda a América através de uma larga diversidade de opções. 
No entanto, o salto havia sofrido uma diminuição e se tornado mais discreto antes de voltar finíssimo e alto no século seguinte, como aponta Estevão (2018).

Nessa mesma época, no Oriente Médio, pequenos saltos foram agregados aos sapatos tradicionais, segundo o que descreve Barreiros (2019), enquanto na China a tradição determinava que os pés (membros inferiores) deveriam ter entre 8 a $10 \mathrm{~cm}$. Para isso, as moças quebravam e amarravam seus dedos, usavam pequenas botas (geralmente de tecidos vermelhos, que simbolizavam a cor da sorte). Dentro da tradição do Japão, havia os chinelos geta, que eram estruturados em madeira e possuíam duas traves na parte de baixo. Tinham o propósito de equilibrar a proporção dos quimonos rituais, segundo Gonzaga (2018). Outro fato histórico importante apontado por Estevão (2018) era que os homens que compunham a elite europeia usavam sapatos de salto nos esportes relacionados a cavalo, pois estas eram práticas e atividades ligadas ao universo masculino e o salto simbolizava a virilidade masculina. Entretanto, esses hábitos já pertenciam aos cavaleiros persas.

Entre 1730 e 1740, por mudanças comportamentais e governamentais, os homens deixaram de usar os sapatos de salto alto e estes se tornaram, exclusivamente, pertencentes à ala feminina, pois, nessa época, as mulheres lutavam por diferenciação, quando passaram a fazer uso do cigarro, do corte de cabelo curto e na luta pelos seus direitos, passaram a usar peças do vestuário masculino, entre elas o sapato de salto alto. Bossan (2013) e Brito (2013), mostram que os calçados da atualidade são frutos da descoberta do italiano Salvatore Ferragamo, que nasceu em uma pequena cidade perto de Nápoles no século XVIII. Oriundo de família simples, ele produziu o calçado de sua irmã para a primeira comunhão. Pegando gosto pela prática, trabalhou confeccionando calçados em Nápoles, partindo depois para os Estados Unidos para realizar seus estudos. Segundo Estevão (2018), no século XIX, com o surgimento da fotografia, as mulheres passaram a ser fotografadas nuas, utilizando apenas um único acessório: um sapato de salto que tinha a finalidade de acentuar as curvas do corpo. É através dessa finalidade que se cria a conotação erótica em torno da peça, como descrito por Estevão (2018), além da ideia associativa às antigas prostituas, que faziam uso e deram fama a este acessório. Nessa mesma época, mais precisamente final da década de 1950, a indústria de calçados passou a ser valorizada pela produção de sapatos de salto produzidos à mão, conforme nos diz Marreto (2018) no site “Área da mulher.r7”. Com isso, o estilista inglês Charles Worth, considerado o "pai da alta-costura", ganhou destaque perante a realeza europeia através da confecção de sapatos.

Para Estevão (2018), no final do século XIX e começo do século XX, os sapatos de salto alto foram totalmente popularizados, além de se tornarem símbolo de elegância, devido à 
grande contribuição que as estrelas de Hollywood deram ao desfilarem com diversos saltos em seus pés. No período pós-guerra, em 1950, o estilista Christian Dior e o designer Roger Vivier (criadores dos sapatos usados pela Rainha Elizabeth em sua coroação em 1953), desenvolveram o salto agulha, mais conhecido como stiletto. Contudo, por ser um sapato composto de um salto tão fino, feito de metal e semelhante a uma lâmina, seu uso se tornou proibido em prédios públicos da Europa devido aos danos causados ao chão. Estevão (2018) descreve que a primeira fábrica de sapatos de salto alto surgiu em Nova York, em 1888, trazendo o estilo francês para dentro do continente americano, porém, o ápice desse objeto ocorreu apenas na virada do século $\mathrm{XX}$ quando as mulheres optaram por saias mais curtas e com isso passaram a exibir as pernas, além de conquistarem a liberdade do uso do salto alto com a intenção de enaltecer a sensualidade feminina.

Atualmente, o estilo de sapato está relacionado ao estilo de cada mulher, que pode ou não ter seu gosto voltado para o salto alto. Contudo, a feminilidade e elegância que esse calçado traz a qualquer mulher é algo indiscutível. Porém, como dica de moda, as mulheres que desejam obter um sapato coringa capaz de dar, segundo Botero (2018), um up em qualquer produção, devem investir no bom e clássico scarpin com salto alto.

Portanto, a cultura é o maior determinante dos desejos, das necessidades e dos comportamentos que a pessoa aprende desde a infância com a família e outras instituições. E o salto, nesse contexto, pode ser entendido como um fenômeno cultural, sendo a persistência do uso dos calçados de salto alto um fenômeno cultural (BRITO, 2013, p. 7).

Muito mais do que deixar a mulher elegante, sexy e bonita, o uso do salto alto é algo cultural e, desde muito cedo, a menina já aprende que aquele objeto é desejo de todas as mulheres porque as deixam lindas e poderosas.

A simbologia do sapato é muito forte dentro do universo do imaginário masculino, segundo os autores Kaetsu, Lanchi e Pépece (2013). Para eles, essa simbologia histórica é mais importante para a comercialização de um objeto do que sua própria funcionalidade, por isso o sapato é muito mais do que um objeto que protege os pés do contato com o chão. Sua função não é tão simples. Ele fala muito sobre a mulher que o está usando, mostra sua sensualidade, seu poder, até seu pertencimento a algum grupo. 


\section{Sonhos e trabalho}

O salto alto é objeto de desejo de toda menina, que desde muito cedo imita a mãe colocando os seus sapatos e desfilando pela casa se sentindo poderosa e sublime, ou sonhando com o conto de fadas da Cinderela, no qual o príncipe procura sua amada pelo sapato de cristal que a linda dama perdeu na noite anterior, no baile, esperando o príncipe encantado que irá levá-la para o seu castelo e viverem felizes para sempre. Após a adolescência, a pequena descobre que o sonho de ser princesa não existe mais, no entanto, a ideia de poder e sedução que existe perante esse objeto se perpetua até a sua vida adulta, quando a mulher é cobrada (e muitas vezes exigida) a usar esse calçado de salto alto. Em grandes festas e cerimônias, além da roupa impecável, a mulher deve se portar em cima de um sapato de salto alto que lhe deixe mais bonita, elegante e atraente aos olhos masculinos, não sendo bem vista uma mulher linda e bem vestida em uma festa com um sapato sem salto ou com pouco salto, fazendo com que as mulheres se sujeitem a situações de sofrimento e dores para poderem mostrar que são poderosas e elegantes. Porém, isso não é algo que se limita a apenas algumas horas de dias de grandes festividades, para algumas mulheres, a realidade do "algoz" de 15 ou $20 \mathrm{~cm}$ se faz presente em sua rotina diária profissional, pois várias empresas exigem que suas funcionárias utilizem salto alto em todo o período de trabalho, principalmente as que desempenham algum cargo de comando, como a gerência. Se está à frente das telas da televisão ou qualquer atitude profissional de destaque, existe a cobrança do uso desse objeto considerado símbolo de poder e feminilidade, porque, para a nossa cultura machista, a mulher empoderada que pode ditar regras e manifestar atitudes de poder (as poucas que conseguem os cargos de destaque dentro das empresas) devem estar vestidas impecavelmente e montadas em um salto alto, e quanto mais alto, mais poderosa é considerada essa mulher, precisando ela suportar toda a forma de dor, pois, para ser respeitada como a pessoa que irá comandar toda uma equipe, deve utilizar o sapato de salto alto, uma vez que para quem está no comando com tantas responsabilidades e exigências, o uso desse acessório não deve ser nenhum problema, pois o que é um sapato diante de tantas tarefas importantes que ela deve desenvolver dentro da empresa.

O consumo do salto alto no trabalho é dotado de muita simbologia. Observando os objetivos do trabalho, pode-se concluir que existem diversos significados para o uso do salto alto nas atividades profissionais pelas mulheres estudadas, e destacam-se aqueles relacionados à imagem feminina, o poder e a liderança necessária para exercer o trabalho, e ainda, o respeito que ele representa, frente aos pares do ambiente profissional. O salto alto é tido como um artefato que atribui qualidades necessárias ao bom desempenho e imagem pessoal frente a clientes, fornecedores, chefia e colegas de trabalho (KAETSU; LACHI; PEPECE, p. 6). 
As dores que as mulheres sofrem quando necessitam passar muito tempo sobre esses calçados, principalmente dentro do ambiente de trabalho necessitando que sejam eficientes e competentes, se mantendo em cima desse objeto por seis ou mais horas trabalhadas, as tornam mais valorizadas pelos seus superiores e são aquelas que fazem uso dos maiores saltos. Existem empresas que, juntamente com o uniforme, têm como exigência o uso do salto alto, o chamado dress code, que é o código de vestimenta das empresas, Cunha, em seu blog, relata a fala do advogado especializado na área do trabalho, Werner Keller, que diz que se dentro do código de vestimenta da empresa pode ter a obrigatoriedade o uso do salto alto, isso não terá nenhum problema se houver um bom senso, porém também pode ser entendido como ato de rejeição para algumas devido à existência de mulheres que não podem utilizar esse tipo de calçado devido a problemas de saúde; portanto, a empresa está respaldada pela lei, pois não existe proibição para tal exigência, salvando-se aquelas que provam que possuem problemas de saúde que podem ser agravados com o uso do salto alto, como problemas de coluna, calcanhar e joelho, precisando sempre se explicar para o não uso de tal objeto, não apenas para seus superiores, como para os demais companheiros de trabalho que lançam um olhar questionador.

O salto alto pode dificultar o andar da pessoa, pois este limita o contato do pé com o chão impedindo a distribuição completa da absorção do impacto podendo ocasionar vários problemas e até fraturas. Um número grande mulheres, com o uso do salto alto, desenvolve joanete, problemas na coluna, varizes, e seus fins de tardes são tortuosos com os pés extremamente doloridos, quase com o dobro do tamanho, ocasionando vários problemas futuros em seus membros inferiores. Além de tudo isso, normalmente, a maioria dos ambientes de serviço possui escadas, dificultando ainda mais a mobilidade da mulher que está utilizando esse tipo de calçado.

Uma das críticas que o movimento feminista faz, é da subordinação da mulher em relação ao uso do salto alto, argumentando que esse é utilizado para agradar o imaginário do fetiche masculino, colocando a imagem feminina apenas como um objeto de desejo do homem em todos os ambientes em que a mulher está presente. Outro grande problema, além do sofrimento, é a dificuldade de correr com esse objeto, principalmente em momentos de apuros como necessitar fugir de um possível agressor ou um violentador, sendo o salto alto um vilão excepcional nesse momento de perigo.

Contudo, segundo Cunha, em seu blog, existe uma tendência para o uso dos sapatos baixos, e essa tendência também está ocorrendo no mundo corporativo, não deixando de lado a elegância e a feminilidade. Por outo lado, a mulher mais confortável e mais à vontade demonstra mais segurança e confiança. Até no mundo da moda, como relata Fernanda Casagrande, no dia 
29 de maio de 2018, no site Purepeople, a atriz Kristen Stewart utilizou um kitten heels (sapatos de salto fino e baixo conhecido também como gatinho) no festival de Cannes, causando alvoroço e espanto para o mundo da moda. Em contrapartida, Passos descreve uma pesquisadora italiana que obteve, como resultado de uma pesquisa, os benefícios do salto alto para as mulheres que fazem uso desse objeto na vida sexual devido ao fortalecimento do assoalho pélvico, em função do ângulo que os pés ficam em relação ao chão, tendo uma menor atividade elétrica dos músculos pélvicos, ficando mais relaxados e podendo obter mais força de contração.

\section{Fetichismo}

O salto alto, por deixar o corpo da mulher em evidência devido manter suas costas retas, os seios mais para frente e os quadris mais em movimento, é um objeto de fetiche na mente dos homens, deixando-os mais excitados. Por outro lado, as mulheres podem se sentir mais sensuais e sedutoras, como demonstra a musa dos cinemas Sharon Stone, no filme Instinto Selvagem, no qual aparece usando uma roupa elegante e sensual, calçando sapatos de salto alto, realizando a sua famosa cruzada de pernas. Porém, tudo isso é fruto do patriarcado machista em que vivemos. Herdamos esse pensamento que a mulher tem que ficar bonita e atraente para chamar a atenção do homem, muitas vezes sendo tratadas simplesmente como mero objeto de prazer masculino, mesmo que algumas relatem que usam porque elas gostam e se sentem bonitas, mas a grande questão é como a ideia de se sentir bonita foi apresentada para ela, pois, desde sua primeira infância, é dito para menina que a mulher fica linda em vestidos longos e com salto alto. Essa ideia é tão fortemente interiorizada dentro do mundo feminino que até as que se dizem feministas como a atriz Juliana Paes, descrita por Pedro Tadeu, no Diário de Notícias do dia 14 de Novembro de 2017, como uma pessoa que se diz feminista e usa salto alto para se enfeitar porque gosta e se sente bonita. Segundo o mesmo autor, o uso do salto alto pelas mulheres deveria ser um ato livre de sua vontade e não algo a que ela foi conformada, ensinada e muitas vezes obrigada a usar.

Quando adentramos o universo feminino, um assunto em comum entre as mulheres está relacionado aos sapatos e entre os diversos modelos desenvolvidos e apresentados pela indústria calçadista está o queridinho da grande maioria: o sapato de salto alto. Mesmo no mundo adolescente, no qual a grande maioria das meninas são adeptas do tênis, o uso do salto alto tem se iniciado cada vez mais cedo e se tornando cada vez mais frequente. Segundo Foucault (2005), o discurso é um jogo de escritura, de leitura e de troca, no qual são considerados unicamente os 
signos, isto é, o discurso ultrapassa sua condição de significar passando a significante. Assim, para que ocorra esse discurso, é necessário que haja um contexto que interfira e que também seja interferido por ele, desde que haja um "controle" originado em sistemas acordados pela sociedade.

Isso acontece, pois a análise do discurso em volta do salto alto é algo extremamente estratégico e bem elaborado, na qual estarão presentes múltiplas "falas" que não adentram apenas o mundo do discurso oral, mas também o discurso escrito através de imagens, gestos, cores, cheiros, entre outros, embutindo, assim, todo um anseio no mundo adolescente para o uso do sapato de salto alto. Segundo Pinto (2002), toda a comunicação é ou faz parte de um ritual social com regras e convenções que devem ser seguidas e toda a contextualização passa por mediações exigidas naquele meio social. O sujeito do discurso se torna parte da mediação, ou seja, ele deixa de ser o agente passivo (emissor ou receptor) para se tornar o agente ativo que se envolve em todas as etapas do sistema. Assim, o receptor recebe a mensagem decodificando-a com a intenção de proteger o discurso, para então se tornar o emissor ao respondê-lo.

Dessa forma, a posição que o sujeito ocupará nas estruturas da comunicação será totalmente independente, pois o seu embasamento estará no imaginário construído dentro e pelo contexto histórico-social, ou seja, as palavras iniciam a estruturação, porém o imaginário é que complementará a interpretação da mensagem recebida. Segundo Orlandi (1992), a grande contribuição da Análise de Discurso é observar os modos de construção do imaginário necessário na produção dos sentidos. Para Pinto (2002), o processo de produção-circulaçãoconsumo dos sentidos de um texto passa por duas dimensões, o ideológico e o de poder, denominado "semiose social". Segundo Prachine (2006), no mundo de aparências em que entramos, uma vez que aprendemos a ser o que somos por meio das regras e subvenções subjacentes aos discursos que dominamos, o ideológico fica a cargo das marcas ou traços formulados pela geração de sentidos encontrados na superfície textual ou as pré-construções desenvolvidas pelas inferências e pressuposições outorgadas ao bom senso, que são repartidas entre os sujeitos da estrutura comunicacional. Segundo Pinto (2002), essas inferências e pressuposições geram, de modo direto ou indireto, as relações de poder desiguais e relativas às diferenças sociais entre os participantes desse processo. Já o poder se torna a segunda dimensão do signo social, pois as relações de poder estão sempre presentes dentro dos processos de comunicação, seja de forma implícita ou explícita, como aponta Pinto (2002).

Contudo, quando analisamos o contexto histórico-social da evolução de tal acessório, notamos que ele deixou de ser um simples ornamento da construção vestumentária e passou a 
ser a verdadeira joia que embeleza os pés femininos. Entretanto, mais que isso, o salto alto se tornou um mito não apenas pelo fato de proteger os pés ou aumentar a estatura de quem o usa, mas por carregar características extremamente fortes como fetiche, poder, sedução e feminilidade. Assim, dentro da Análise do Discurso, o poder representa uma dimensão analítica e não concreta, estando também ligada ao fetichismo, o que faz do salto alto um instrumento de discurso extremamente poderoso, respaldado na percepção do estímulo.

A palavra fetiche dentro do discurso histórico-social teve sua forma aplicada em diferentes contextos. $\mathrm{Na}$ antiguidade, o fetiche estava relacionado a alguns tratados como forma de denunciar as religiões "bárbaras", ou seja, conceituava a adoração a "ídolos de barro e madeira". Porém, com o evoluir do tempo, a palavra fetiche passou a ser utilizada como forma de adoração irracional, o que ocasionou o surgimento de uma segunda compreensão, a marxista, que traduzia como uma falsa consciência e alienação a expressão "fetichismo do produto". Para Marx, as pessoas outorgam valores secretos aos produtos, que passam a ser um "hieróglifo social" a ser decodificado (STELLE, 1997). A patologia sexual denominada de fetichismo surgiu, pela primeira vez, no livro de Krafft-Ebing intitulado Psychopathia Sexualis, tendo sua primeira edição lançada em 1886 em que são mostrados estudos de caso de pacientes com parafilias. Os termos "masoquismo" e "sadomasoquismo" foram criados por Kraffit-Ebing; contudo; a linguagem trabalhada por ele é totalmente poética, mas os tratamentos utilizados naquela época, hoje seriam mal vistos, perversos e doentios. Dentro da sua obra, o fetichismo é dado como uma neurose cerebral, sendo explicado da seguinte maneira:

(...) investe de sensações voluptuosas a representação imaginária de partes isoladas do corpo ou peças do vestuário do sexo oposto, ou até mesmo simples pedaços de pano. (...) Em geral, quando o fetiche está ausente, o coito se torna impossível ou só pode ser realizado sob a influência da respectiva representação imaginária, podendo, mesmo assim, não trazer satisfação (KRAFFT-EBBING, 2000, p. 8)

As análises de Krafft-Ebing foram realizadas no final do século XIX, quando a sexualidade era totalmente indiscutível, ficando claro em seus textos o seu julgamento moral. Ele acreditava que a abstinência do desejo, a erradicação do comportamento parafílico ou até mesmo a hidroterapia (banhos com amarras em banheiras) e a faradização (forma inicial do eletrochoque) eram a cura para as psicopatias sexuais, incluindo o fetichismo (SELLERS, 2000). Somente no ano de 1887, Alfred Binet apresentou, pela primeira vez, o termo "fetichismo" com acepção e sentido psicológicos através do ensaio Le Fetishisme Dans L'amour, no qual deixava claro que a obsessão fetichista estava ligada a objetos inanimados, e que estes eram a causa do desejo e do prazer sexual, exceto para os casos denominados de 
“fetichista em amor" (fétichiste en amour), ou seja, a obsessão por partes do corpo as quais não transmitiam desejo sexual. Segundo Binet (1888): "afirma que todos o somos mais ou menos; e que há uma dose constante de fetichismo no amor mais comum". Contudo, o fetichismo apresenta um fator extremamente importante e este demonstra que a parafilia é proeminentemente masculina:

\begin{abstract}
Depois de estudar fantasias eróticas e comportamento sexual por muitos anos, o psiquiatra Robert Stoller concluiu que "fetichizar é a norma para homens, não para mulheres". Isso não quer dizer que as mulheres não se interessem por partes do corpo ou roupas sensuais. Mas elas não parecem "desejá-las ardentemente" da mesma forma que os homens o fazem. (Essa é uma questão importante se queremos explorar o apelo para as mulheres de roupas que os homens tratam como fetiches) (STEELE, 1997, p. 20).
\end{abstract}

Freud, em sua obra intitulada "Três Ensaios Sobre a Teoria da Sexualidade", de 1905, e no artigo "Fetichismo", de 1927, explicita esse conceito da seguinte maneira:

(...) o fetiche, na verdade, é um substituto para o pênis. (...) trata-se de um pênis que em casos normais deveria ter sido abandonado ao longo do desenvolvimento, mas que o fetiche tem a função de preservar. (...) o fetiche é um substituto do pênis da mulher (da mãe) em que o menininho outrora acreditou e do qual - bem sabemos o porquê - não quer de modo algum abdicar (FREUD, 2007, p. 162)

Freud faz referência à castração e ao medo que a castração provoca no menino. Quando o menino percebe que sua mãe não possui pênis, sente que o próprio pênis está em perigo; então, consegue um substituto para o falo "perdido" da mãe (FREUD, 2007). Nesse caso, o falo é algo simbólico. Lacan, psicanalista freudiano e celebridade importante da corrente de pensamento denominada Estruturalismo, descreve o objeto de fetiche em seu n'O Seminário, livro 4, quando disserta sobre a relação de objeto. Para Lacan o fetiche se aproxima do simbólico, por isso diversos autores concordam que o fetichismo está no limite entre a neurose e a perversão. Ainda segundo Lacan, essa afirmação ocorre por meio do "Esquema do Véu", cuja importância reside em conseguirmos situar corretamente os elementos que entram em jogo na instauração da relação fetichista. Esse esquema mostra que "com a presença da cortina, aquilo que está mais além, como falta, tende a se realizar como imagem. Sobre o véu, pinta-se a ausência" (LACAN, 1995, p. 157). Então, o objeto assume o lugar dessa ausência, dessa forma, como o fetiche está ligado ao simbólico, e a fantasia ao imaginário, a moda toma posse dele para assim representar o desejo, a luxúria e o glamour.

Então, dentro da publicidade, o desejo se torna o responsável pelo impulso de compra. A troca de objetos efetivada pelos indivíduos na sociedade é o que media todas as relações 
humanas (KEHL, 2004 apud RAMOS, 2006), sendo que esses objetos são completos de significados, "culturalmente e socialmente adequados e favoráveis" (RAMOS, 2006, p. 29). Logo, o desejo não está no objeto a ser comprado, mas na carência (seja ela social ou pessoal) a ser suprida (VESTERGAARD; SCHRODER, 2004 apud RAMOS, 2006), e que em momento algum será suprida. É nesse espaço que a publicidade age nos fornecendo objetos que são promessas de sucesso e de satisfação garantida (RAMOS, 2004). Os objetos a serem desejados são lançados pelos meios de comunicação (RAMOS, 2004). Guy Debord (1931-1994), em $A$ Sociedade do Espetáculo, afirma que as revistas femininas mostram o estilo mais favorável para o mercado, os lugares da moda (DEBORD, 2004), obrigando, assim, as pessoas a se adequarem naquilo que o mercado lhes oferece, já que a indústria não pode satisfazer cada indivíduo que compõe a sociedade. Então, tudo tem que ser encaixado no modelo prédeterminado, na imagem mais próxima daquela que é pessoal e individual ao sujeito, distanciando-se este do que realmente é e aproximando-se do que foi criado pelo outro (RAMOS, 2004). Segundo o sociólogo e professor universitário chileno Moulian (1999 apud BUSATO, 2001, p. 164) “essa transformação não só realiza uma necessidade do sistema, mas também do indivíduo, e que os objetos contribuem para a realização das possibilidades do eu”.

\section{Considerações finais}

Por meio dessa pesquisa sobre a história e o uso do salto alto, realizada através de fatos históricos, blogs e artigo científico, obteve-se como resultado uma longa e rica história em torno desse objeto que muitos acreditam que serve apenas para proteção dos pés e aumento da estatura, mas, muito mais do que isso, existe todo um contexto de poder, sedução, feminilidade e fetiche, que o relaciona a quem o possui (BARREIROS, 2019). Na Antiguidade, diferenciava os nobres dos plebeus, ainda hoje esse objeto continua sendo motivo de distinção de pessoas. Nas festas, a mulher considerada a mais bela, além do seu belo vestido, o salto que está utilizando diz muito sobre o poder que ela exerce, igualmente referido no ambiente de trabalho, onde a mulher que exerce a liderança e o poder é a que possui o maior salto. Como ponto positivo podemos citar o fortalecimento do assoalho pélvico pelo uso desse calçado, pois a falta de contato total do pé com o solo favorece um relaxamento da musculatura pélvica, melhorando sua contração no momento ato sexual.

Nesse trabalho, pudemos concluir que existem acessórios que dizem muito sobre as pessoas que os estão utilizando (neste caso, o salto alto); este esteve presente desde a história remota da humanidade e se faz presente até os dias atuais, passando por todas as transformações 
que a espécie humana sofreu, desde o seu uso por homens, chegando até as mulheres. Com o objetivo de impedir o contato dos pés com a sujeira da rua, muitas mulheres, nessa época, utilizavam o sapato com salto extremamente alto, acima de $30 \mathrm{~cm}$, ocasionando uma dificuldade muito grande para seu caminhar, chegando ao ponto de precisarem ser carregadas por seus criados, o que representava o poder desse objeto como destaque de uma classe social. Esse objeto, depois de um tempo, sumiu do vestuário masculino ficando exclusivo ao universo feminino, utilizado em ambientes de grandes festas e celebrações, nas quais a mulher de maior destaque era aquela que estivesse além de bem vestida, também com um belo salto alto que a deixava mais bonita e empoderada, mesmo sentindo um grande desconforto. Passou-se essa situação para além de ambientes de festividades, foi também adotada para o ambiente de trabalho, principalmente quando a mulher exerce um cargo de destaque. Esse objeto é tão poderoso que acabou entrando no imaginário masculino, levando os homens a grandes desejos por mulheres que o usam, devido ao contorno que esse calçado dá ao corpo da mulher.

\section{REFERÊNCIAS}

BARREIROS, I. Pé de lótus mulheres chinesas fraturavam os próprios pés para conseguirem casar. UOL Aventuras da História, 23 ago. 2019. Disponível em:

https://aventurasnahistoria.uol.com.br/noticias/reportagem/historia-pe-de-lotus-quandomulheres-chinesas-fraturavam-os-proprios-pes-para-casar.phtml Acesso em: 12 jun. 2020.

BOTTERO. Salto alto: conheça a história do sapato queridinho das mulheres. Blog Bottero, 1 jun. 2018. Disponível em: https://bottero.net/blog/dicas/historia-sapatos-salto-alto/. Acesso em: 15 jun. 2020.

BRANCHINE JOSEFINA, V. O discurso do salto alto. Brasília, DF: Centro universitário de Brasília, maio 2006. Disponível em:

https://repositorio.uniceub.br/jspui/bitstream/123456789/1836/2/20277557.pdf. Acesso em: 14 jun. 2020.

BUSATO, C. Visões do consumo: um diálogo com o mundo. Prosa UNIDERP, v. 1, n. 1, p. 161-172, set. 2001.

BRITO ALMEIDA, G. Uma análise acerca da hegemonia dos sapatos de saltos altos ao longo da história. In: $9^{\circ}$ Colóquio: moda fortaleza. 2013. Disponível em:

https://silo.tips/download/uma-analise-acerca-da-hegemonia-dos-sapatos-de-saltos-altos-aolongo-da-historia Acesso em: 10 jun. 2020

CUNHA, K. Desmestificando o salto alto no trabalho. Blog do uniforme inteligente, 26 abr. 2018. Disponível em: http://blog.styl.com.br/2018/04/26/desmistificando-o-salto-alto-notrabalho/. Acesso em: 10 jun. 2020. 
DEBORD, G. A sociedade do espetáculo: comentários sobre a sociedade do espetáculo. Rio de Janeiro: Contraponto, 2000.

ESTEVÃO MARIA, I. Salto alto: as curiosidades em torno da peça símbolo da feminilidade. Blog Metrópoles, 28 ago. 2018. Disponível em: https://www.metropoles.com/colunasblogs/ilca-maria-estevao/salto-alto-historia-curiosidades. Acesso em: 06 jun. 2020.

FOUCAULT, M. A ordem do discurso. 12. ed. São Paulo: Loyola, 2005.

FREUD, S. Um caso de histeria, três ensaios sobre a teoria da sexualidade e outros trabalhos. Rio de Janeiro: Imago, 200. v. VII. p. 1901-1905.

FREUD, S. Fetichismo: [1927]. In: Escritos sobre a psicologia do inconsciente. Fetichismo (1927). Rio de Janeiro: Imago, 2007. v. III. p. 1923-1940.

GONZAGA, L. M. O salto alto na história. Blog Márcia Peltier. Disponível em:

http://www.marciapeltier.com.br/o-salto-alto-na-

historia/\#: :text=Nobres\%20aderiram $\% 20 \mathrm{em} \% 20$ massa $\% 20$ ao,caminhar $\% 20$ no $\% 20 \mathrm{cal} \% \mathrm{C} 3$

\%A7amento\%20de\%20pedras. Acesso em: 5 jun. 2020

HANCOCK, R. J. Porque os homens deixaram de usar saia, salto alto e peruca. Eı País, 2 jan. 2018. Disponível em:

https://brasil.elpais.com/brasil/2018/01/25/cultura/1516881949_162680.html

Acesso em: 05 jun. 2020.

KAETSU TERCI, S.; LANCHI HANCKE, C. A.; PEPECE COUTINHO, M. O. O significado do uso salto alto no ambiente de trabalho. RAIMED - Revista de Administração IMED, v. 5, n. 3, p. 269-276, set./dez. 2015.

LACAN, J. O seminário: livro 4, a relação de objeto. Rio de Janeiro: Jorge Zahar Ed., 1995.

MARRETO, J. Quem inventou o salto alto? Área da Mulher, 16 abr. 2018. Disponível em: https://areademulher.r7.com/curiosidades/quem-inventou-o-salto-alto/. Acesso em: 6 jun. 2020.

MYLIUS, M. S. É preciso conhecer um calçado. Tecnicouro, n.1, p. 10-18, jan. 1998.

ORLANDI, E. P. As formas do silêncio: no movimento dos sentidos. Campinas: Editora da UNICAMP, 1992.

OUROFINO, A. G. O fetiche na fotografia de moda e a representação feminina: editoriais da revista vogue brasil de 2007 a 2011. Revista Linhas, Florianópolis, v. 16, n. 32, p. 221-245, set./dez. 2015. Disponível em:

https://www.periodicos.udesc.br/index.php/linhas/article/view/1984723816322015221.

Acesso em: 14 jun. 2020.

PINTO, M. J. Comunicacão e discurso. 2. ed. São Paulo: Hacker Editores, 2002.

RBS. Consumidores exigentes e tecnologias avançadas ditam as regras do sapato do futuro. Grupo RBS-RS 2013. Disponível em: 
http://www.clicrbs.com.br/especial/sc/variedades-sc/19,0,2861401,Consumidores-exigentese-tecnologias-avancadas-ditam-as-regras-do-sapato-do-futuro.html. Acesso em: 16 jun. 2020.

RAMOS, K. F. A. Sedução e desejo: representações da mulher nos anúncios de perfumes femininos. Orientadora: Susana Madeira Dobal Jordan. 2006. 144 f. Dissertação (Mestrado em Comunicação) - Universidade de Brasília, Brasília, 2006

SELLERS, T. Introdução. In: KRAFFT-EBING, R. V. Psychopathia sexualis: as histórias de caso. Trad. Claudia Berliner. São Paulo: Martins Fontes, 2000.

STEELE, V. Fetiche: moda, sexo \& poder. Trad. Alexandre Abranches Jordão. Rio de Janeiro: Rocco, 1997.

TADEU, P. Uma feminista pode usar salto? Diário de Notícias, 14 nov. 2017. Disponível em: https://www.dn.pt/opiniao/opiniao-dn/pedro-tadeu/uma-feminista-pode-usar-saltos-altos8914754.html. Acesso em: 6 jun. 2020.

\section{Como referenciar este artigo}

ATTAB, R. M. C.; FERNANDES, P. S. A representatividade do salto alto. Revista on line de Política e Gestão Educacional, Araraquara, v. 24, n. esp. 3, p. 1793-1808, dez. 2020. eISSN:1519-9029. DOI: https://doi.org/10.22633/rpge.v24iesp3.14277

Submetido em: 10/01/2020

Revisões requeridas: 20/07/2020

Aprovado em: 30/10/2020

Publicado em: 30/11/2020 